\title{
The Market Lives on Death: The Endocolonizing Logic of the Fascist Moment ${ }^{1}$
}

This article poses the question of whether what we are witnessing today can be properly described as "fascistic." It argues that it can if we understand fascism as an attack on liberal-democracy resulting from the now chronic (rather than acute) crisis of capitalism. Like the fascism of the twentieth century, this entails an endocolonizing logic that nonetheless relinquishes its claim on a future increasingly imperilled by the nature of the Covid-19 pandemic in the context of the impending climate emergency.

Keywords: endocolonialism, fascism, populism, democracy, crisis, spectacle

1 This article is based on the Introduction to my edited volume Spectres of Fascism: Historical, Theoretical and Contemporary Perspectives (Gandesha 2020a) and well as short pieces previously published in openDemocracy. I wish to thank editors Felipe Ziotti Narita and Jeremiah Morelock for the invitation to contribute the piece as well as to three anonymous referees for their very helpful comments on an earlier draft. 
It seems that fascism has returned. Nevertheless, be careful when using the word "fascism." The term is often used so indiscriminately-especially by the Left — to vilify one's political opponents that it is in continual danger of losing all meaning. In what sense, then, can we say that what we are witnessing throughout the globe is the re-emergence of fascism? Writing in the pages of the New Left Review two years ago, Dylan Riley (2018) argued trenchantly that if we compare $20^{\text {th }}$ century fascism with contemporary authoritarians such as Trump across four axes-geo-political dynamics; the relation between class and nation; developments within civil society; and political parties - there is no persuasive evidence that what we are confronted with today is anything approaching fascism. And, indeed, according to Slavoj Žižek's influential gloss on Walter Benjamin, the authoritarianism that we see around us today does not arise in response to what could reasonably be called a "failed revolution." Of course, there were the Arab Spring and the Occupy movements, but they did not come remotely close to challenging the domination of capital.

However, as Samir Amin (2014) has perceptively argued, fascism does not have to entirely conform to the $20^{\text {th }}$ century mould and may be simply understood as being comprised of two essential elements. The first is that it is the response to the crisis of capitalism. The second is that it constitutes a categorical rejection of "democracy" by way of an appeal to collective identities — often condensed in the figure of a "strong" leader-tied to a notion of the "people."

Yet, two refinements ought to be made to Amin's definition. The first such refinement is that the very notion of crisis needs to be rethought. Under neoliberalism, crisis is no longer to be regarded as discrete and cyclical but rather as continuous and enduring. It is not an event but a syndrome or a condition; to use a medical metaphor, crisis is no longer "acute" but "chronic." This means, of course, that fascism is always something of a haunting presence within a neoliberalism that is, one could say, co-extensive with a deep and abiding fissure within the social order. Once precisely touted as the antidote to authoritarianism (Hayek 2007; Foucault 2010), neoliberalism deepens and exacerbates authoritarian tendencies that are coextensive with capitalism itself. That, at the end of the day, capitalism, now faced with crushing inequalities (see Piketty's flawed but nonetheless useful Capital and Ideology, 2020), will preserve itself by any means necessary. As Theodor W. Adorno once argued, the real threat of fascism comes from within not from outside of capitalist or liberal democracy.

The pandemic undoubtedly overdetermines neoliberalism's endemic crisis and the word crisis, it is important to remember, derives from 
the Greek krisis (decision) and krinein (to decide) (Adorno 1998). In the original Greek, the word also means the turning point of a malady, that decisive point at which time the condition of the patient manifestly improves or deteriorates. In other words, if the crisis of our neoliberal social order-greatly over-determined and exacerbated by the Covd-19 pandemic- - is chronic rather than acute, then it is a time at which the figure of the sovereign, the entity that decides on the exception (Carl Schmitt), comes to cast a particularly long and dark shadow over our times.

Over the past several years, if not decades, ghosts of fascism have, therefore, escaped their $20^{\text {th }}$ century crypts and come to haunt our present. With the global Covid-19 pandemic, however, we face the prospect of our "Reichstag Fire" moment. This was an arson attack on the German legislature exactly four weeks after Adolf Hitler was sworn in as Chancellor, allegedly carried out by Marinus van der Lubbe, a Dutch Council Communist. The Nazis immediately claimed that the fire was the result of a communist plot, and it became the pretext for their seizure of power (Machtergreifung) and total co-ordination of the state (Gleichschaltung). Close to a dozen states, from Azerbaijan to Togo, have already used the pandemic to arrogate more power to themselves. Indeed, this development has been particularly visible in Washington, Budapest, and Delhi.

Donald J. Trump claimed "total authority" for the Oval Office in opposition to state governors who had sought to loosen lockdown measures earlier. While he quickly backtracked on this claim, he nonetheless called upon his supporters in blue states to resist lockdown measures and "liberate" themselves from the authority of Democratic governors in an effort to get the wheels of the economy turning again, and has closed the US's borders and suspended immigration for sixty days. The implicit identity of the health of the bodies of individual (white) Americans with that of the US body politic is clear.

Viktor Orbán, Hungary's president, having previously curtailed the autonomy of the courts, has indefinitely suspended the legislative branch of government, eliminating, in the process, the key liberal-democratic principle of institutional limits on executive authority-he now rules by decree. Orbán has consistently, over the years, attacked George Soros, whom he has taken as the metonym of the baleful "globalist," which is to say, Jewish, influence on Hungarian politics. Former Canadian Prime Minister, Stephen Harper, is one of Orbán's many admirers.

The RSS in India - the quasi-fascist Hindu nationalist (Hindutva) force behind Modi-has, in a classically fascistic move, characterized its 
Islamic "enemy" as the abject carrier of the Covid-19 virus. The hashtags "CoronaJihad" and "BioJihad" have proliferated via Twitter, as Jason Stanley and Federico Finchelstein (2020) have recently indicated via Indian journalist Rana Ayyub, just as the Nazis used typhus as the pretext for excluding Jews, isolating them in ghettos and ultimately murdering them. The targeting of Muslims comes in the aftermath, of course, of the unconstitutional annexation of Kashmir and changes to the Citizenship Act that explicitly and unapologetically discriminate against this oppressed and reviled minority community.

The Covid-19 pandemic, less of a definite event than an amorphous syndrome, perhaps plays an analogous role to that of the Reichstag fire in consolidating sovereign power. As it has been widely observed, the pandemic brings into visibility the deep-seated precarity constitutive of the neo-liberal order-one that only the very wealthy can seemingly escape.

The second such refinement is that fascism is not a categorical rejection of democracy per se but rather a rejection of its liberal form. As Vladimir Putin recently mused, perhaps liberal democracy is obsolete (Financial Times 2019). Yet, like leaders of fascist movements of the $20^{\text {th }}$ century, Putin makes an appeal of a certain sort to the idea of democracy (Rousseau's "general will as opposed to what he calls the "will of all", see Rousseau 1968). He does so by claiming to embody the will of the demos people or Volk, and this is what makes such claims especially dangerous today. There is, in other words, considerable overlap between $20^{\text {th }}$ century fascism, on the one hand, and contemporary forms of right-wing or authoritarian populism — which are often correctly described as "neo-fascist" or post-fascist," as Enzo traverso recently indicated-on the other.

An important difference between $20^{\text {th }}$ and $21^{\text {st }}$ century forms of fascism is that while the former in Germany, under the pretext of the post-Reichstag Fire emergency, abolished the right of assembly, freedom of the press, and ultimately, elections by suspending the Weimar Constitution, right-populists today are committed, at least nominally and for the time being, to contesting elections, although they are quite happy to dispense with many of its corollaries such as the rule of law, respect for minority rights, the division of powers, etc. In fact, they are mobilizing divisions so effectively that they are winning elections and maintaining popular support for the time being, particularly in Hungary and India.

But under the current pandemic, such a commitment to elections might, of course, change rather abruptly. This may appear to be far- 
-fetched or even alarmist; however, if we recall that, in the run-up to the mid-term elections in 2018, Trump tweeted thinly-veiled threats of violence were the G.O.P. to suffer setbacks at the polls, and prior to that was his invocation of the "Second Amendment people," it was not beyond the realm of the possible. In late April, 2020, Michigan protesters, whom Trump called "very good people," demonstrated little compunction about hauling their assault weapons to the legislature to intimidate bulletproof vest-clad lawmakers. This was, we now know in retrospect, a prelude to Trump's exhortation to his followers to storm Capitol Hill on January $6^{\text {th }}, 2001$.

The Republican Party's commitment to the basic features of liberal-democracy seem to be very much in question, as is evinced by engaging in gerrymandering and voter suppression. In contrast with its ostracization from the Republican Party in 2016 by the G.O.P.'s establishment, Trumpism has, today, fully captured the party's spirit. This was made clear by the ousting of Liz Cheney, daughter of former Vice President Dick Cheney, and third ranking Republican in the House of Representatives, who is one of the very few high-ranking Republican figures to challenge the mendacious Trumpian narrative that the election had been "stolen." Several conservative U.S. states are now in the process of enacting legislation that would further restrict voting rights and gerrymander electoral districts to favour Republican candidates (Cf. Gardner et al. 2021).

A vitally important difference between the fascism of the $20^{\text {th }}$ century and that of the present century is how each of them conceive of time. To be sure, Hitler's dream of a "1000-year Reich" was spatially oriented, insofar as it was based on the securing of Lebensraum to the east for the German Volk. However, what was more important than space in Nazi thinking was time, insofar as fascism was, in its own perverse way, "utopian" and "revolutionary" oriented to a bright new future for the "Aryan race." In Being and Time, card-carrying member of the Nazi Party, Martin Heidegger (1962), elevated the temporal modality of the future over both the past and the present. The future would be secured by retrieving the forgotten experiences at the origin of the Ancient Greek understanding of Being.

Present-day fascism, in contrast, takes refuge exclusively in the past as such: in a supposedly "great" America before the Civil Rights Act (if not before the Civil War); in an authentic homeland of the Magyars in Hungary; and in a purified India for Hindus (Hindustan). In other words, contemporary fascism makes little or no claim on the future in an era of its ecologically planned obsolescence. In this, it is, as Aimé Césaire (1950) had 
already pointed out in Discourse on Colonialism, a form of European colonialism applied to Europe itself-endocolonialism, as it were. Endcolonialism, for Césaire as well as for Arendt and Traverso, entailed the application of colonial modes of domination by European states to other European states and nations. Today, as we have seen in the Greek case, its weapons are German banks rather than tanks. As I have written elsewhere (Gandesha 2020b), we see this as well in the willingness of that model of kumbaya "liberal multiculturalism" - the Canadian stateto deploy the logic of the exception to permit on-going large energy infrastructure projects (hydro, LNG, and bitumen) under conditions

Specters of fascism

loom, then, as

a response to the chronic financial and ecological crisis of capitalism. Fascism in the $20^{\text {th }}$ century offered, in part, a solution to the economic slump via an acceleration of the extraction of absolute and relative surplus-value from living labor by smashing the revolutionary Left, independent trade unions, and other working-class institutions.

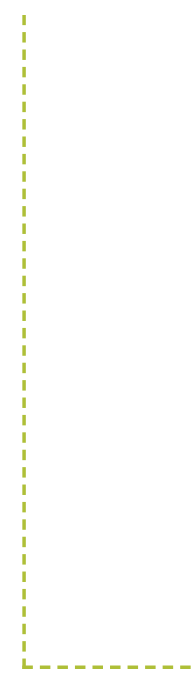
of a Covid-19 lockdown. Recalling the weaponization of disease in the earliest days of contact between Indigene and Colonizer, this puts already vulnerable Indigenous communities at serious risk of a health catastrophe. ${ }^{2}$ The same logic can be discerned in the Modi Government's resource extraction agenda driving the war on India's tribal peoples (Adivasis) in Chhattisgarh, not to mention in Jair Bolsonaro's iron-fisted developmental programme in the Amazon basin.

Specters of fascism loom, then, as a response to the chronic financial and ecological crisis of capitalism. Fascism in the $20^{\text {th }}$ century offered, in part, a solution to the economic slump via an acceleration of the extraction of absolute and relative surplus-value from living labor by smashing the revolutionary Left, independent trade unions, and other working-class institutions. This was, indeed, the original meaning of Mussolini's (and Gentile's) idea of fascism based on the image of what was called, in Latin, fasces, a bundle of rods and protruding axe blade symbolizing the penal powers of the Roman state wielded by the magistrate. Fascism entailed, then, the binding together of the rods of the state, capital, and labour. It is perhaps telling that both the US and French Republics adopted and maintained this proto-fascistic Roman symbolism through the $18^{\text {th }}$ and $19^{\text {th }}$ centuries.

In contrast to its anti-human $20^{\text {th }}$ century form, contemporary "post-human" fascism centres on a deepening of resource extraction on the very precipice of massive deskilling of labour, and widespread automation and employment of robotics, machine learning, and artificial intelligence to wit - the prospective obsolescence of humanity itself. Such a logic entails what, in Critique of Black Reason, Achille Mbembe (2017) calls the "becoming Black of the world," the creation of "abandoned subjects":

2 As the meme attacking the government's granting exceptions for extractive industries (so-called "essential services") from the Covid-19 health protocols reads: As the meme goes "Genocide is not an essential service!" 
There are no more workers as such. There are only laboring nomads. If yesterday's drama of the subject was exploitation by capital, the tragedy of the multitude today is that they are unable to be exploited at all. They are abandoned subjects, relegated to the role of a "superfluous humanity."

This superfluousness now becomes clear as governments, by omission or commission amidst the pandemic, put members of society deemed surplus as well as workers, particularly people of colour, at grave risk of contracting or even dying from the virus (a recent UCSF study conducted in San Francisco's Mission District showed that 95\% of positive cases were Latinx). Of course, it could be argued that human labour has never appeared more "essential" than in this historical moment. Yet, states are also showing themselves quite willing to put essential workers at such an extreme risk as to even die en masse for want of PPE, for example. MTA conductor and writer, Sujatha Gidla (2020), reports her co-workers as saying "we are not essential, we are sacrificial" (New York Times, May 6).

In his depiction of the aftermath of catastrophe, possibly nuclear war, in Endgame, Samuel Beckett (1964) presents the destruction of nature as taking a specific spatial configuration in which the dialectic of time itself has seemingly come to a standstill. He shows, in coldly unsentimental though often humorously ribald terms, the obsolescence of human beings, reduced as they are to pure existence, and subordinated to the inscrutable machinations of geopolitical forces beyond their understanding and control. The necessary supplement to Endgame, according to Stanley Cavell (1969), is Kubric's Cold War masterpiece Dr. Strangelove.

Beckett depicts the parents of his anti-hero, Hamm, as literally reduced to a form of societal refuse, having been confined to garbage binsperhaps signifying for us today, all-too painfully, the perilous state of nursing homes - warehouse-coffins for human beings poised somewhere between life and death, waiting for an end to the excruciating game of waiting. They wax nostalgic ("Ah, the good old days," sighs Nell) about the days when they were provided with sand rather than sawdust in their metallic cloisters, a signifier of happier times spent on the beach rather than of a nature that is now "corpsed." The catastrophe of the present and its relation to the recent past forms a continuum of the same unfolding disaster Walter Benjamin writes about in his final text "On the Concept of History" before his desperate flight from the Nazis and consequent suicide in Port Bou. Today, governments seem prepared to sacrifice the elderly, the infirm, poor, indigent, black and brown to the iron laws of the market. Republican Lieutenant Governor of Texas, Dan Patrick, recently suggested that grandparents might consider sacrificing 
their health and lives for their grandchildren, which is to say, for the health of the economy. But this logic is nothing new. It was previously discernible in each press release from myriad corporate head offices of massive downsizings, producing an immediate, dramatic uptick in their share prices. The market lives on death.

If we take as our definition the classic account of fascism as that revolutionary mass movement comprised of an alliance between industrial capital and the petite bourgeoisie ranged against the working class and its political organizations, in the context of imperialist rivalries and discrete capitalist crises of overproduction, then it is far from clear that what we face today can be described as "fascism." After the defeat of organized labour, there is precious little resistance to dead labor's machinic extraction of surplus value from living. Such a defeat clears the way for redoubled colonization and endocolonization, racism, militarism, and, ultimately, war.

The endocolonizing logic of contemporary fascism becomes particularly manifest in the context of the contemporary cityscape. Here we can extrapolate the rationality of the post-colonial periphery in the dynamic of policing, which, of course now takes on new meaning, with the election of the Joe Biden and his Vice President former San Francisco DA Kamala Harris. If behind every fascism can be discerned a failed revolution, then it is possible to see the contours of the contemporary fascism moment not simply in the rise of the hard right turn of the Republican Party with Newt Gingrich and the Tea Party, but in Nixon's campaign against the protest movement, the Black Panther Party, in particular. Far from the Biden-Harris triumph as representing a decisive defeat of a quasi-fascistic Trumpism, what it does is reinforce the failure of the very revolution that Harris' parents sought to participate in. In this sense, Harris is the uncanny double of Angela Davis, whom another Bay Area prosecutor sought to execute on trumped up charges as was so well documented in Shola Lynch's moving 2012 film, Free Angela and All Political Prisoners. A glance at Ousmane Sembène's classic film Borom Sarret (The Wagoner) draws out, proleptically, some of the features of the endocolonial cityscape today. After a brief discussion of the film, I fast-forward to a viral YouTube video of African-American author and activist, Kimberley Jones', critique of the concept of the "looter" in the context of \#BLM protests.

\section{Policing the Post-Colony}

Widely regarded as the first film made in Black Africa, Borom Sarret (The Wagoner) by Ousmane Sembène provides a profound glimpse 
of immediate post-colonial reality. ${ }^{3}$ Made in 1963 upon the auteur's return from learning his craft at the Gorkii Studios in Moscow, it portrays the unfolding of a day in the life of a cart driver in Dakar, Senegal. Its formal minimalism enables Borom Sarret to reveal several layers of complexity. In the economical space of approximately 18 minutes, it discloses the structural violence established and consolidated through colonial class and gender relationships that live on, uncannily, in the post-independence period. It is a vivid and crystalline cinematic depiction of what Frantz Fanon had called just two years earlier in Wretched of the Earth, the "pitfalls of national consciousness" and the way in which precisely such an imaginary served to mask the real, which is to say ruthlessly exploitative relationships among citizens of newly "liberated" states. It provokes suspicion of the now ubiquitous idea, at least in the global north, that the abstraction of racial identification alone could ever be an organizing principle of solidarity and therefore politics.

We follow the driver and are privy to his interior monologue, delivered by Sembène himself while he transports a series of passengers and materials to their various destinations. The cart driver considers the exertions of an unemployed man futile and irritating; he is coldly unsympathetic to his plight. He is accosted by a severely crippled yet reasonably affable beggar who asks for money but is even less solicitous and ignores him: "there are so many of them, they are like flies." Yet the driver is more than happy to pay the well-fed and well-dressed griot or folk singer who builds up the driver's ego ideal by his ingratiating and obsequious praise of the warrior-identity of his ancestors.

Then there's the solemn father whom the driver transports with the corpse of his infant child to the cemetery, only to be turned away because his papers are not in order; he is, we learn, a "foreigner." The artificial borders of the "nation-state" constructed ex nihilo by the colonial powers continue to enact their violence, unremittingly, on the most vulnerable. The driver carefully places the corpse of the child on the ground and drives way, leaving the bereft father to suffer alone.

The narrative begins to tighten with the approach of a well-dressed and apparently wealthy African man who wishes to be taken to the formerly French quarter of Dakar - the Plateau; here, cart drivers require special permits. The man is moving to the Plateau, he tells the driver. The camera pans in the direction of the former European quarter to reveal a shockingly different cityscape. As the soundtrack shifts from

3 This section draws upon Gandesha 2020c. 
the syncopated rhythms and xalam (lute) of traditional Senegalese music to $18^{\text {th }}$ century European classical music, the sand and rock give way to paved streets, the horse-drawn carts to orderly modern automobile traffic. In a few short miles, we traverse centuries.

As soon as the driver nervously enters the Plateau, he is immediately confronted by a scowling police officer who promptly issues him a fine and confiscates his cart. As he is writing the ticket, the officer steps on the wagoner's medal, most likely for the driver's service in the French army. Meanwhile, the wealthy passenger absconds in an awaiting car. In this single gesture, the continuity of the corruptions of Empire is laid bare. Racial solidarity is revealed for the myth that it is. The police are there to protect the wealthy Blacks from poor Blacks, whose labour power is nonetheless required for the production of wealth; the inclusion of the worker is premised on their spatial exclusion. They are what Jacques Rancière (2013) calls "the part that has no part."

The driver returns home with his horse, devastated and bewildered. His wife rises, matter-of-factly gives him their infant child to look after, promises that they would have food that evening, and leaves. According to the Director of NYU's Institute of Afro-American Affairs, Manthia Diawara, the common interpretation-consistent with themes in Sembène's other films - is that she is off to participate in sex work and this was not to be disparaged but accepted as a legitimate form of labour; sex workers were to be accepted as proletarians and neither stigmatized nor condemned, as they were, of course, by the imams.

Today in the midst of the global uprising, amidst the Covid19 pandemic, against anti-Black and anti-Indigenous state violence, and the related re-emergence of fascism, Borom Sarrett can be seen to be, in Walter Benjamin's terms, blasted out of the continuum of history and shot through with "now time" (Jetztzeit). Such "now time" crystallizes in at least three ways.

First, as alluded to above, the return of fascism provokes a reconsideration of Césaire's theory of endocolonialism-fascism as the application of techniques of domination perfected in Europe's African and Asian colonies to the European context itself. The fascist imaginary was anchored to German and Italian colonial projects in Africa and the US Republic's genocidal westward expansion.

Second, at the same time, however, the brutalities of policing cannot be reduced to "White supremacy" alone, but must also be situated in class and gender relationships. The role of the police is to protect private property, which is to say, the separation between the worker and the means of production. Separation from the means of production is the 
condition for the possibility of exploitation as workers must sell their labour power which is rendered abstract, temporally quantifiable and measurable. Borom Sarrett makes this explicit insofar as the wagoner is literally deprived of his own means of production at the moment that his cart is confiscated. The abstract violence of this gesture forces his wife-both means of production and worker in one-into the nexus of the sex industry in order to engage in socially reproductive labour.

Third, the police also, of course, maintain the specifically spatial separation common to virtually all African cities, that between the natives' quarters or the "Medina," on the one hand, and the settlers' quarters the „Plateau," on the other, which, as Sembène shows us, is taken over by the post-colonial African bourgeoisie.

Today, in the West, but especially North America, we see the intimate ties between fascism on the one hand and an increasingly militarized police apparatus. Here, we see the brutal over-policing of Black people in US and Canadian inner cities and Indigenous peoples in their own territories, in particular. What Fanon calls the "well-built town" of the settler anticipates the White "gated community" fortified by increasingly privatized and militarized police forces which function, for all intents and purposes, like armies of occupation in the precincts of the poor and indigent. A society of separation; a society of the post-colonial spectacle. This becomes especially clear in Kimberly Jones's (2020) powerful analysis of looting entitled "How Can We Win?"

\section{The Consummation of Consumption ${ }^{4}$}

Guy Debord's (1966) reflection on the Watts Uprising of 1965 stands in a certain relationship to the events of May 1968 and also, of course, to what happened in Minneapolis in the wake of the murder of George Floyd. What constitutes the axis is, I would suggest, that these are three examples of the "events" in the sense meant by Alain Badiou. For Badiou (2015), the event signifies a moment at which the impossible becomes possible, and the moments comprising this axis are three moments at which time capitalist society's own fantasy or dream about itself is profoundly disturbed.

Four aspects of Jones's analysis are especially noteworthy:

(1) Jones begins with an attack on the condemnatory response of wealthy Blacks to the uprising which is, to refer to Langston Hughes,

4 This section draws on Gandesha 2020d.

Today, in the West, but especially North America, we see the intimate ties between fascism on the one hand and an increasingly militarized police apparatus. Here, we see the brutal over-policing of Black people in US and Canadian inner cities and Indigenous peoples in their own territories, in particular. 
"Go Slow." Jones is clear that she is viewing things not from the perspective of Black people per se but from the perspective of poor Blacks. So, her focus isn't simply on the difference between Identities, that is, Black and White, but also the differences with them, ie. the differences within the Black community, which includes substantive class differences and conflicts within this community over the very meaning of the event itself. Here it is possible to argue, I think, that those middle-class Blacks who condemn the protestors, rioters and looters, and, in the process, offer an apology for an unjust and violent social order, like colonial and post-colonial elites, identify with the aggressor (Gandesha 2018) as a response to the traumatic material of history.

(2) Jones's discussion of the boardgame Monopoly as analogy for the failure of the social contract in the United States is powerful, and her invocation of Tulsa and Rosewood show the extent to which Black socio-economic and political gains have resulted in what Terry Smith calls a White backlash or Whitelash for short. Donald J Trump may be regarded as the personification of this in his rancorous attempt to systematically undo the legacy of the Obama White House, including and especially the Affordable Care Act, even if, at the end of the day, as critics like Cornel West and Keeanga-Yamahtta Taylor, among others, rightly point out that under Obama the socioeconomic conditions of Black Americans actually worsened to a greater extent than their White counterparts.

(3) Jones claims that the social contract is broken. Here I would challenge her claim somewhat with reference to Jamaican political theorist Charles Mills's (1999) concept of the racial contract. This is the idea that the contractarian tradition from Hobbes through Rawls is premised upon an unacknowledged exclusion of Black and Brown people and therefore a hidden yet no less consequential White Supremacy. One could say that this is the repressed content of political theory.

For example, the Lockean idea that North America was terra nullius - that the land was "nobody's"-lent legitimacy to the settler colonial project-which, by the way, was a project that consisted of little other than looting on a grand scale. So perhaps it's not a matter of the contract being broken at all but functioning as it should. The point is not that the liberal-democratic social contract ought to be adhered to by way of equal treatment under the law but fundamentally rewritten to move beyond the premises of liberal-democracy itself. Its deferred dreams are dreams deferred infinitely for Black and Indigenous peoples. Langston Hughes: "The prize is unattainable."

(4) The last and, in my view, most important claim worthy of note 
is that her rejoinder to wealthy Blacks takes the form of a defence of the figure of the "looter," which she defetishizes by refusing a fixation on what it is they're doing, ie. egregiously smashing and grabbing commodities, but also why they are doing it. And this is an indictment of US capitalism, if not capitalism as a whole. Again, as Marx indicates with his concept of primitive accumulation in Chapter 26 of Capital, this is a system that is made possible by systematic looting (embodying the real primitivism that is then projected onto its victims):

The discovery of gold and silver in America, the extirpation, enslavement and entombment in mines of the aboriginal population, the beginning of the conquest and looting of the East Indies, the turning of Africa into a warren for the commercial hunting of black-skins, signaled the rosy dawn of the era of capitalist production.

If we turn to Guy Debord's article "The Decline and Fall of the Spectacle-Commodity Economy," from the Issue \#10 of Situationiste Internationale published in March, 1966, it will be possible to draw out some of the radical implications of Jones's analysis.

Like Jones, Debord draws attention to the almost universal condemnation of the Watts Uprising. The Watts uprising began on August 11, 1965, when 21-year-old Marquette Frey, an African-American man, was pulled over by the police, and a tussle ensued leading to six days of civil unrest amidst accounts of police brutality. Debord singles out remarks by the head of the NAACP at the time Roy Wilkins, who argued that the riot "ought to be put down with all necessary force." Like Jones, Debord understands the uprising not in racial but in class terms, referring to MLK Jr's statement in a recent Paris lecture that Watts wasn't a "race" but a "class" riot. What drives the Blacks of Watts is proletarian consciousness, according to Debord, which means consciousness that they neither are masters of their own activities nor of their own lives.

The crux of Debord's analysis aims at an inversion of the characterization of looters as the embodiment of animalistic drives. He does so by deploying a concept that he would elaborate in his most famous book two years later, which, in fact, gave direction to the events of May, 1968, and this is the concept of the spectacle. According to Debord, the spectacle is capital accumulated to the point where it becomes an image. The spectacular society is the society that creates amidst real misery and deprivation the appearance or fantasy of affluence and abundance. (It is a systematic "turning of a blind eye" as Maxine put it.) 
The spectacle represents a new level of the fetishism of the commodity form which is an object with a certain use value that satisfies determinate human needs but that is, nonetheless, produced in order to realize its exchange value or profit. For Debord, the looters, far from being animals, represented a human response to dehumanizing conditions, namely, the fact that capitalist society, characterized by generalized commodity production, is a society in which relations between things appear as relations between people and relations between people resemble relations between things.

By challenging the almost theological sanctity of the commodity, the looters re-establish human relationships grounded in gift and potlash economies. For Debord, the racist and colonial "hierarchy" of the society of the spectacle, people of colour, but particularly black people, are

The possibility of cross-racial solidarity is of vital importance to grasp the particular and universal significance of the uprisings and in the process to make of it

more than a "racial" event, for this is exactly what the far-right want. Rather, we must situate the uprisings that we're seeing within the larger context of a society in which inequalities are deepening; it is also

important to place recent developments within in the context of

a history of social struggles, from Watts in 1965 to Paris in 1968 to Minneapolis in 2020. reduced to the status of things. Insofar as the looters directly circumvent the logic of exchange with the demand for use, which is to say, the satisfaction of needs, however false such needs may be, they resist such a status. He argues: "The flames of Watts consummated the system of consumption (...). Once it is no longer bought, the commodity lies open to criticism and alteration, whatever particular form it may take." Yet, such flames immediately call the police into action. The policeman is the active servant of the commodity, the person in complete submission to the commodity, whose job it is to ensure that a given product of human labor remains a commodity with the magical property of having to be paid for instead of becoming a mere refrigerator or rifle-a passive, inanimate object, subject to anyone who comes along to make use of it. In rejecting the humiliation of being subject to police, the blacks are at the same time rejecting the humiliation of being subject to commodities (Debord 1966). The social contract, to reiterate, is not broken but functions all too well for it is a contract geared to the maintenance of private property.

Returning to the question I started with—namely, the possibility of cross-racial solidarity - it is of vital importance to grasp the particular and universal significance of the uprisings and in the process to make of it more than a "racial" event, for this is exactly what the far-right want. Rather, we must situate the uprisings that we're seeing within the larger context of a society in which inequalities are deepening; it is also important to place recent developments within in the context of a history of social struggles, from Watts in 1965 to Paris in 1968 to Minneapolis in 2020. It is vitally important to understand extreme forms of police violence not as effects of a mystical, transhistorical White supremacy, but rather as a manifestation of a racism that flows from the vicissitudes 
of a social order mediated by the commodity-spectacle, grounded in the sanctification of private property under deepening forms of socio-economic inequality that nonetheless hits Black and Indigenous communities especially hard. This social order is a historical one-an order that came into being and one from which it is possible for us to emancipate ourselves.

\section{Conclusion}

Contemporary fascism emerges from the phenomenon of accelerated global migration flows resulting from the economic, social, and political violence (new forms of primitive accumulation) attendant upon the global reconstitution of the relations of production. It responds to the increasing ontological insecurity of citizens of these states-inestimably bolstered now by the pandemic — whose fear is increasingly and effectively mobilized against myriad strangers turned into enemies. Such mobilization is based on the acute awareness that, under the late form of neoliberalism, the line between citizen and migrant, parvenu and pariah—in other words, "genuine" and "superfluous" humanity-is increasingly blurred. Capitalism has always embodied a sacrificial logic, and this lies at the heart of its authoritarian potential today. This logic deepens when workers, particularly white workers, hand in hand with the lower middle class, come to identify with rather than contest the power of the aggressor.

Yet, as dire as the situation may be, there are hopeful signs of growing labour militancy, as was recently demonstrated by striking workers at Amazon, Instacart, Shipt, and Whole Foods on May Day, who protested what they considered to be their employers' woefully inadequate responses to the pandemic. The global health emergency, moreover, has demonstrated that the integrity of societies cannot be indexed to the prosperity and well-being of its most affluent but most indigent members. It has decisively shown that healthcare cannot be tied to conditions of employment but must be understood, as Bernie Sanders repeated over and over again in his bid for the Democratic presidential nomination, as a basic human right. It has highlighted the nihilistic illusions of the "possessive individualism" on which shifting sands of the entire neoliberal order is based. It has seriously revived, with great urgency, the discussion of the admittedly fraught and contested idea of Universal Basic Income. The pandemic has doubtlessly, as I have argued, constituted an opening for a further authoritarian consolidation of power, but, at the same time, it has also opened space for imagining a very different kind of society. 
Which path we take will be a matter of organizing, which is to say, political engagement and struggle.

\section{References}

Adorno, Theodor W. 1998. "Critique." In Critical Models: Interventions and Catchwords, edited by Theodor W. Adorno. Translated by Henry Pickford. New York: Columbia University Press.

Amin, Samir. 2014. "The Return of Fascism Within Contemporary Capitalism." Monthly Review, September 1. https://monthlyreview. org/2014/09/01/the-return-of-fascism-in-contemporary-capitalism/.

Badiou, Alain. 2015. The Communist Hypothesis. Translated by David Macey and Steve Corcoran. London: Verso.

Beckett, Samuel. 1964. Endgame: a Play in One Act Followed by Act Without Words, A Mime for One Player. London: Faber and Faber.

Cavell, Stanley. 1969. "Ending the Waiting Game: A Reading of Beckett's Endgame." In Must We Mean What We Say: A book of Essays, 115-162. Cambridge: Cambridge University Press.

Césaire, Aimé. 1972. Discourse on Colonialism. Translated by Joan Pinkham. New York: Monthly Review Press.

Debord, Guy. 1966. "The Rise and Fall of the Spectacle-Commodity." Translated by Ken Knabb. Internationale Situationniste 10(2). https:// www.cddc.vt.edu/sionline/si/decline.html.

Financial Times. 2019. "Vladimir Putin Says That Liberalism Has become Obsolete." Financial Times, June 27.

Finchelstein, Federico, and Jason Stanley. 2020. "The Fascist Politics of the Pandemic." Project Syndicate, May 4. https://www.project-syndicate.org/commentary/coronavirus-fuels-fascist-politics-by-federicofinchelstein-and-jason-stanley-2020-05.

Foucault, Michel. 2010. The Birth of Biopolitics: Lectures at the Collège de France, 1978-1979, edited by Michel Senellart. Translated by Graham Burchell. New York: Picador.

Gandesha, Samir. 2018. "Identifying with the Aggressor: From the 'Authoritarian' to the 'Neo-Liberal' Personality." Constellations 25(1): 147-164.

- 2020a. "Introduction." In Spectres of Fascism: Historical, Theoretical and Contemporary Perspectives, edited by Samir Gandesha. London: Pluto Press.

2020b. "Canada’s Battle Against First Nations Shows Slide into Authoritarianism.” Truthout, February 1. https://truthout.org/artic- 
les/canadas-battle-against-first-nations-shows-slide-towardauthoritarianism/.

2020c. "Ousman Sembene and the Part that Has No Part." OpenDemocracy, July 3. https://www.opendemocracy.net/en/ ousmane-sembène-and-the-part-that-has-no-part/.

. 2020d. "The Consummation of Consumption, Parts 1 and 2." OpenDemocracy, October 2. https://www.opendemocracy.net/en/ consummation-consumption-1/ and https://www.opendemocracy. net/en/can-europe-make-it/consummation-consumption-2/.

Gardner, Amy, Kate Rabinowitz, and Harry Stevens. 2021. "How GOP-backed Voting Measures Could Create Hurdles for Tens of Millions of Voters." Washington Post, March 11.

Gidla, Sujatha. 2020. "We Are Not Essential, We Are Sacrificial." New York Times, May 6. https:/www.nytimes.com/2020/05/05/opinion/ coronavirus-nyc-subway.html.

Hayek, Friedrich. 2007. The Road to Serfdom: Texts and Documents, edited by Bruce Caldwell. Chicago: Chicago University Press.

Heidegger, Martin. 1962. Being and Time. Translated by John Macquarrie and Edward Robinson. San Francisco: Harper and Row.

Jones, Kimberley. 2020. “How Can We Win?” YouTube, accessed June 9, 2020, https://www.youtube.com/watch?v=llci8MVh8J4.

Mbembe, Achille. 2017. Critique of Black Reason. Translated by Laurent Dubois. Durham: Duke University Press.

Mills, Charles. 1999. The Racial Contract. Ithaca: Cornell University Press.

Piketty, Thomas. 2020. Capital and Ideology. Translated by Albert Goldhammer. Cambridge: Belknap Press.

Rancière, Jacques. 2013. The Politics of Aesthetics: The Distribution of the Sensible. Edited and translated by Gabriel Rockhill. London: Bloomsbury.

Riley, Dylan. 2018. "Editorial: What is Trump?" New Left Review 114: $5-31$.

Rousseau, Jean-Jacques. 1968. The Social Contract. Translated by Maurice Cranston. London: Penguin.

Žižek, Slavoj. 2009. "The Palestinian Question: The Couple Symptom / Fetish Islamo-Fascism, Christo-Fascism, Zionism - Mieux Vaut un Désastre qu'un Désêtre.” Lacan.com, accessed November 23, 2021, www.lacan.com/essays/?page_id=261. 
SAMIR GANDESHA, Ph.D. - is a Professor of Humanities and Director of the Institute for the Humanities of Simon Fraser University (Canada). He is co-editor with Lars Rensmann of Arendt and Adorno: Political and Philosophical Investigations (Stanford, 2012) and co-editor with Johan Hartle of Spell of Capital: Reification and Spectacle (University of Amsterdam Press, 2017) and Aesthetic Marx (Bloomsbury Press, 2017), also with Johan Hartle. More recently, he edited Spectres of Fascism: Historical, Theoretical and International Perspectives (Pluto, 2020), which is presently being translated into Turkish and Portuguese, and co-edited (with Peyman Vahabzadeh) Crossing Borders: Essays in Honour of Ian H. Angus, Beyond Phenomenology and Critique (Arbeiter Ring, 2020).

\section{Address:}

Institute for the Humanities

Simon Fraser University

8888 University Drive, Burnaby - B.C.

Canada V5A 1 S6

email: samir_gandesha@sfu.ca

\section{Citation:}

Gandesha, Samir. 2021. "The Market Lives on Death: The Endocolonizing Logic of the Fascist Moment." Praktyka Teoretyczna 42(4): 93-110. DOI: $10.14746 /$ prt2021.4.4

\section{Autor: Samir Gandesha}

Tytuł: Rynek żywi się śmiercią: Endokolonizacyjna logika momentu faszystowskiego Abstrakt: Artykuł stawia pytanie o to, czy obserwowane obecnie procesy mogą być określone jako faszystowskie. Przedstawiona argumentacja wskazuje, że tak - jeśli rozumiemy faszyzm jako atak na liberalną demokrację, wynikający z chronicznego raczej (niż nagłego) kryzysu kapitalizmu. Tak jak w XX-wiecznym faszyzmie, obejmuje on kolonizację ciał, która jednak zrzeka się roszczeń do przyszłości w obliczu pandemii Covid-19 i w kontekście wyzwania klimatycznego.

Słowa kluczowe: endokolonializm, faszyzm, populizm, demokracja, kryzys, spektakl 